\title{
Artikel Penelitian
}

\section{Pengaruh Penilaian Prestasi Kerja dan Kompensasi terhadap Kinerja Tenaga Teknis Kefarmasian Non-PNS Instalasi Farmasi RSUP Dr. Hasan Sadikin}

\author{
Rina Winarni, Ahmad Muhtadi, Emma Surahman \\ Fakultas Farmasi, Universitas Padjadjaran, Sumedang, Indonesia
}

\begin{abstract}
Abstrak
Kinerja adalah hasil kerja secara kualitas dan kuantitas yang dicapai oleh seorang pegawai. Penelitian ini bertujuan untuk mengetahui pengaruh penilaian prestasi kerja dan kompensasi terhadap kinerja pegawai Tenaga Teknis Kefarmasian Non-PNS Instalasi Farmasi. Metode yang digunakan adalah metode survei analitik dengan rancangan potong lintang. Sampel yang digunakan 102 karyawan instalasi farmasi kompetensi Tenaga Teknis Kefarmasian dengan status kepegawaian Non-PNS. Pengumpulan data menggunakan kuesioner dan dianalisis menggunakan analisis jalur. Hipotesis pertama penilaian prestasi kerja memengaruhi kinerja ( $\mathrm{t}$ hitung 4,038 $>\mathrm{t}$ tabel 1,984). Hipotesis kedua adalah kompensasi memengaruhi kinerja ( $\mathrm{t}$ hitung 3,739>t tabel 1,984). Hipotesis ketiga adalah penilaian prestasi kerja memengaruhi kompensasi (t-hitung 10,208 > t tabel 1,984). Penilaian prestasi kerja dan kompensasi berpengaruh sebesar $51,68 \%$ terhadap kinerja pegawai. Penilaian prestasi kerja dan kompensasi masing-masing berpengaruh sebesar $27 \%$ dan $24,68 \%$ sedangkan $48,32 \%$ merupakan variabel lain yang tidak diteliti. Kinerja Tenaga Teknis Kefarmasian Non-PNS Instalasi Farmasi RSUP Dr. Hasan Sadikin dipengaruhi oleh penilaian prestasi kerja dan kompensasi dengan total pengaruh sebesar 51,68\%.
\end{abstract}

Kata kunci: Kinerja, kompensasi, penilaian prestasi kerja, tenaga teknis kefarmasian

\section{The Impact of Performance Appraisal and Compensation to Performance of Pharmacy Technical Personnel Non-Civil Servants at Hasan Sadikin Hospital}

\begin{abstract}
Performance is the result of the quality and quantity of work achieved by an employee. This study aimed to determine the effect of performance appraisal and compensation to performance of Pharmacy Technical Personnel Non Civil Servants. This study used analytic survey with cross-sectional study design. The sample are 102 pharmacy employees. Data was collected by using questionnaires and analyzed using path analysis. The first hypothesis is the performance appraisal affect the performance ( $\mathrm{t}$ value 4,038 $>\mathrm{t}$ table 1.984). The second hypothesis is the compensation affects the performance ( $\mathrm{t}$ value $3.739>\mathrm{t}$ table 1.984). The third hypothesis is the performance appraisal affects the compensation ( $\mathrm{t}$ value $10.208>\mathrm{t}$ table 1.984). Performance appraisal and compensation affected employee performance by $51.68 \%$. Performance appraisal and compensation affected employee performance by $27 \%$ and $24.68 \%$ respectively, while $48.32 \%$ is other variable that is not investigated. Performance of Pharmacy Technical Personnel Non Civil Servants in RSUP DR. Hasan Sadikin is influenced among others by the performance appraisal and compensation with a total effect of $51.68 \%$.
\end{abstract}

Keywords: Compensation, performance, performance appraisal, pharmacy technical personnel

Korespondensi: Rina Winarni, S.Si., Apt, Fakultas Farmasi, Universitas Padjadjaran, Sumedang, Indonesia, email: winarni.rina@yahoo.com

Naskah diterima: 20 Mei 2015, Diterima untuk diterbitkan: 22 Januari 2016, Diterbitkan: 1 Desember 2016 


\section{Pendahuluan}

Instalasi farmasi merupakan salah satu unit pendukung penyelenggaraan pelayanan kesehatan di RSUPDr. Hasan Sadikin(RSHS). Oleh karena itu, sumber daya manusia (SDM) instalasi farmasi merupakan salah satu faktor penentu mutu pelayanan RSHS. Tenaga Teknis Kefarmasian mempunyai jumlah terbanyak yaitu 165 orang dari 218 SDM yang ada di instalasi farmasi. Dari jumlah tersebut sebanyak 102 mempunyai status pegawai Non-PNS. Pegawai yang mempunyai status Non-PNS sebelumnya berstatus pegawai Pra Non-PNS. Perubahan status kepegawaian memengaruhi penghasilan karena pegawai dengan status Non-PNS akan mendapatkan beberapa tunjangan tambahan. Mulai tahun 2014 di RSHS terjadi perubahan pembayaran kompensasi sesuai dengan Keputusan Menteri Keuangan No. 376/KMK.05/2014 dan perubahan penilaian prestasi kerja sesuai dengan Peraturan Pemerintah Nomor 46 Tahun 2011 tentang Penilaian Prestasi Kerja. ${ }^{1,2}$

Penelitian yang dilakukan oleh Pribadi dan Harjanti menunjukkan bahwa penilaian prestasi kerja memiliki pengaruh signifikan terhadap motivasi kerja sehingga adanya peningkatan pada kejelasan, keadilan, feedback, dan dampak dari penilaian prestasi kerja akan meningkatkan motivasi kerja karyawan. ${ }^{3}$ Penelitian yang dilakukan oleh Widyatmini dan Hakim menunjukkan bahwa semakin tinggi kompensasi yang didapatkan, maka semakin tinggi juga kinerja pegawai yang bisa diharapkan. ${ }^{4} \mathrm{Hal}$ ini sejalan dengan penelitian yang dilakukan oleh Ruyatnasih dan Martini yang menyatakan bahwa kompensasi terhadap prestasi karyawan memiliki pengaruh cukup kuat. ${ }^{5}$ Masalah tersebut menjadi latar belakang dilakukannya penelitian pengaruh penilaian prestasi kerja dan kompensasi terhadap kinerja pegawai.

Kinerja, menurut Mangkunagara, adalah hasil kerja secara kualitas dan kuantitas yang dicapai oleh seorang pegawai dalam melaksanakan tugasnya sesuai dengan tanggung jawab yang diberikan kepadanya. ${ }^{6}$ Manajemen kinerja merupakan proses yang melibatkan perencanaan kinerja, pengelolaan kinerja, penilaian kinerja, manfaat kinerja, dan pengembangan kinerja. ${ }^{7}$

Penilaian kinerja adalah proses atasan mengevaluasi kinerja bawahan. ${ }^{8}$ Wiese dan Buckley dalam Sharma, menyatakan bahwa proses penilaian kinerja memungkinkan organisasi untuk mengukur dan mengevaluasi perilaku karyawan individu dan prestasi selama periode waktu tertentu. ${ }^{8}$ Armstrong dalam Daoanis, menggambarkan peran dari penilaian kinerja sebagai alat ukur untuk melihat ke depan mengenai apa yang perlu dilakukan oleh organisasi untuk mencapai tujuan memenuhi tantangan baru. ${ }^{9}$

Penilaian kinerja sangat penting dalam sebuah organisasi yang akan membantu untuk mengevaluasi staf sesuai dengan tugas mereka dan untuk memastikan mereka melakukan pekerjaan sesuai dengan standar yang akan berpengaruh pada kompensasi. Selain itu, penilaian kinerja penting untuk mengidentifikasi keterampilan, kinerja, dan mengetahui kelemahan dan bagaimana cara memperbaikinya. ${ }^{9}$

Denisi dan Pritchaard dalam Selvarajan dan Cloninger dalam penelitian penilaian kinerja telah menunjukkan bahwa karakteristik penilaian kinerja dapat menimbulkan reaksi positif karyawan untuk penilaian kinerja yang pada gilirannya dapat memotivasi karyawan untuk meningkatkan kinerja mereka. ${ }^{10}$

Kompensasi merupakan pengukuran nilai pekerjaan, merancang dan memelihara struktur gaji, membayar kinerja, kompetensi, dan keterampilan. Di samping itu, kompensasi bukan hanya berkaitan dengan uang, akan tetapi juga terkait dengan kompensasi non-keuangan. ${ }^{11}$ Armstrong dalam Patnaik dan Padhi yang menyatakan bahwa manajemen kompensasi merupakan bagian yang integral 
dari pendekatan manajemen sumber daya manusia untuk meningkatkan proktuktivitas, berkaitan dengan desain, implementasi dan pemeliharaan sistem kompensasi yang ditujukan untuk perbaikan organisasi, tim dan kinerja individu. ${ }^{11}$ Dessler dalam Khan dan Mufti, mendefinisikan kompensasi sebagai segala bentuk pembayaran atau imbalan yang diberikan kepada karyawan yang timbul dari pekerjaan mereka. Kompensasi terdiri atas fixed-pay, flexible-pay, benefit. ${ }^{12}$

Ruyatnasih dan Martini (2013) melaporkan bahwa kompensasi merupakan hal yang penting dan strategis karena berhubungan langsung dengan peningkatan semangat kerja, kinerja, dan motivasi karyawan dalam suatu perusahaan. ${ }^{5}$ Penilaian prestasi kerja penting karena dapat memberikan informasi untuk memperbaiki kinerja perusahaan kedepannya, sebagai dasar kompensasi karyawan, pertimbangan dalam keputusan penempatan jabatan, serta kebutuhan pelatihan, perencanaan, dan pengembangan karier karyawan. ${ }^{13}$ Tujuan penelitian ini yaitu mengetahui pengaruh penilaian prestasi kerja dan kompensasi terhadap kinerja Tenaga Teknis Kefarmasian Non-PNS Instalasi Farmasi.

\section{Metode}

Metode penelitian ini menggunakan pendekatan kuantitatif dengan metode survei yaitu penelitian yang mengambil sampel dari suatu populasi dengan menggunakan kuesioner sebagai alat pengumpul data, dan pengambilan data primer dilakukan secara studi potong lintang. Tenaga Teknis Kefarmasian merupakan SDM dengan jumlah terbanyak di Instalasi Farmasi sehingga kinerja Tenaga Teknis Kefarmasian akan memengaruhi mutu dari Instalasi Farmasi. Hal ini yang melatarbelakangi dilakukannya penelitian terhadap Tenaga Teknis Kefarmasian. Populasi dalam penelitian ini adalah karyawan instalasi farmasi dengan kompetensi Tenaga Teknis Kefarmasian dengan status pegawai Non-PNS. Jumlah Tenaga Teknis Non-PNS yang ada di Instalasi Farmasi sebanyak 102 orang. Sampel penelitian yang diambil adalah seluruh populasi dalam penelitian dengan kriteria inklusi karyawan instalasi farmasi dengan kompetensi Tenaga Teknis Kefarmasian status kepegawaian Non-PNS. Sedangkan kriteria eksklusinya karyawan instalasi farmasi kompetensi Tenaga Teknis Kefarmasian status kepegawaian harian lepas, Pra-Non-PNS, dan PNS.

Peneliti menyebarkan kuesioner dengan 36 pernyataan. Pengukuran variabel kompensasi berjumlah 14 pertanyaan yang dikutip dari (Umar Gunu, 2010) dan (Katua Ngui T., Muluku, E., \& Gachunga, H. G., 2014). ${ }^{14,15}$ Jenis pertanyaan dinilai berdasarkan skala Likert dari 1 "sangat tidak setuju hingga 5 "sangat setuju". Kinerja individu diukur dengan 12 pertanyaan yang mengacu kepada aspek-aspek yang dinilai dalam kinerja dengan mengambil sumber dari Hasibuan dalam Mangkunegara dan Umar dalam Mangkunegara. ${ }^{6}$ Jenis pertanyaan dinilai berdasarkan skala Likert dari 1 "sangat tidak setuju hingga 5 "sangat setuju. Sedangkan Penilaian Prestasi Kerja diukur dengan 11 pertanyaan yang diambil dari Selvarajan dan Cloninger. ${ }^{10}$ Jenis pertanyaan dinilai berdasarkan skala Likert dari 1 "sangat tidak setuju" hingga 5 "sangat setuju".

Dilakukan uji pendahuluan yaitu uji validitas kuesioner dengan menggunakan uji korelasi Pearson, dan uji reliabilitas dilakukan dengan cara melihat Alpha Cronbach. ${ }^{16} \mathrm{Uji}$ hipotesis dilakukan menggunakan analisis jalur dengan alasan dapat menjelaskan tata hitung dan hubungan antarvariabel. Analisis jalur ini memungkinkan dilakukannya analisis hubungan antarvariabel dan pengaruh secara simultan atau bersamaan dari variabel bebas terhadap variabel terikat. ${ }^{17}$ Koefisien jalur 


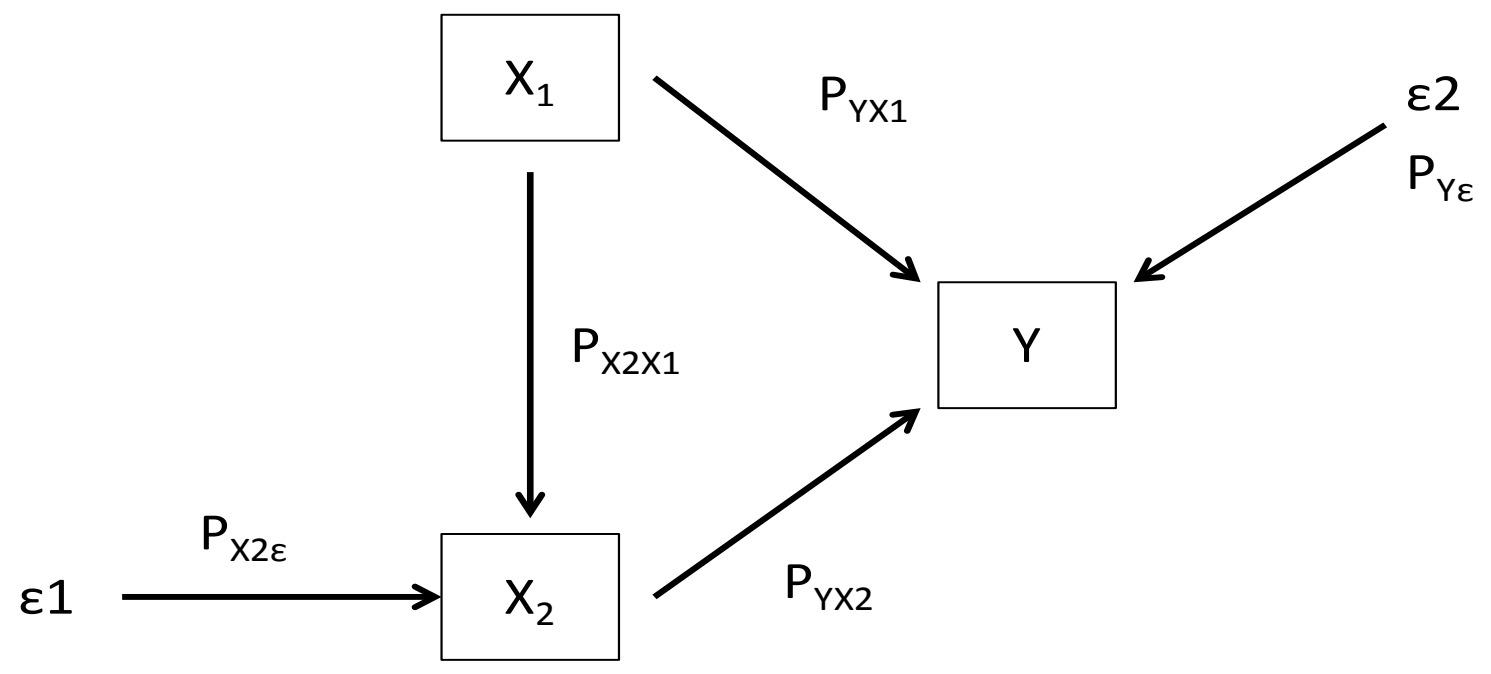

Gambar 1 Diagram Jalur Pengaruh Penilaian Kinerja (X1) melalui Kompensasi (X2) terhadap Keterangan:

\section{Kinerja Pegawai (Y)}

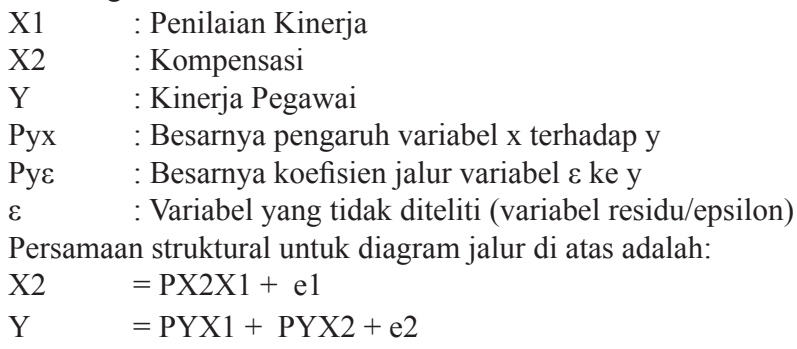

dihitung denganmenggunakansoftwareSPSS. Secara teoretis hubungan antarvaribel yang diteliti akan tampak seperti pada Gambar 1.

\section{Hasil}

Uji pendahuluan terdiri dari uji validitas dan uji reliabilitas yang dilakukan terhadap 30 orang responden. Hasil uji validitas menunjukkan dari 36 indikator diperoleh nilai antara $0,444-0,886(>0,361)$, oleh karena itu seluruhnya dinyatakan valid. Uji reliabilitas menunjukkan koefisien reliabilitas Alpha Cronbach sebesar 0,868 untuk variabel kinerja dan 0,915 untuk variabel penilaian prestasi kerja dan kompensasi. Nilai tersebut berada di atas standar yang ditetapkan yaitu 0,700 sehingga menunjukkan kuesioner tersebut reliabel untuk digunakan dalam penelitian.

Gambaran karakteristik pada responden penelitian sebagai dari 102 Tenaga Teknis Kefarmasian Non PNS yang bekerja di Instalasi Farmasi RSUP Dr. Hasan Sadikin Bandung berusia 20 hingga 30 tahun $(87,3 \%)$.

Tabel 1 Kriteria Penilaian Berdasarkan Persentase

\begin{tabular}{cll}
\hline No & Persentase & Kriteria Penilaian \\
\hline 1 & $0-20$ & Tidak baik \\
2 & $20,01-40$ & Kurang baik \\
3 & $40,01-60$ & Cukup baik \\
4 & $60,01-80$ & Baik \\
5 & $80,01-100$ & Sangat baik \\
\hline
\end{tabular}


Tabel 2 Rekapitulasi Tanggapan Responden terhadap Variabel

\begin{tabular}{clccc}
\hline No. & Variabel & Skor & \% & Keterangan \\
\hline 1 & Kinerja & 415,8 & 81,54 & Sangat baik \\
2 & Penilaian Prestasi Kerja & 389,5 & 76,37 & Baik \\
3 & Kompensasi & 367,9 & 72,14 & Baik \\
\hline
\end{tabular}

Sumber : Pengolahan Data 2015

Selanjutnya, diketahui bahwa karyawan yang paling banyak adalah wanita yakni mencapai $74,5 \%$. Masa kerja karyawan paling banyak adalah yang bekerja di atas 3 tahun, tingkat pendidikan paling banyak adalah D3 Farmasi $(63,7 \%)$, dan status perkawinan yang paling banyak adalah yang telah menikah $(51,0 \%)$.

Dari jawaban kuesioner yang diperoleh, lalu disusun kategori penilaian untuk skor setiap indikator maupun variabel penelitian, rentang persentase penilaian kualitatif setiap indikator dan variabel penelitian berdasarkan penilaian bentuk persentase seperti pada Tabel 1. Rekapitulasi tanggapan responden terhadap variabel kinerja, penilaian prestasi kerja dan kompensasi dapat dilihat pada Tabel 2.

Berdasarkan tanggapan dari responden terhadap variabel terikat yaitu variabel kinerja, diperoleh pernyataan yang memiliki skor paling besar yaitu berusaha jujur dalam menjalankan setiap pekerjaan dengan skor 449 (88,04\%). Indikator yang memiliki skor terendah adalah tingkat kehadiran datang ke kantor sesuai dengan waktu yang ditetapkan nilai $367(71,96 \%)$. Total rata-rata skor variabel kinerja adalah 415,8 atau $81,54 \%$, artinya secara kualitatif masuk dalam kategori sangat baik tanggapannya.

Berdasarkan tanggapan dari responden terhadap variabel tidak bebas yaitu variabel penilaian prestasi kerja, diperoleh rata-rata skor jawaban responden terhadap variabel penilaian prestasi kerja sebesar 389,5 atau $76,37 \%$, yang artinya secara kualitatif tanggapannya masuk ke dalam kategori yang baik. Dapat diketahui juga variabel indikator yang memiliki skor terendah yaitu penilaian kinerja yang diterapkan dapat membedakan antara yang pekerjaan yang bebannya lebih berat/berisiko dengan yang tidak berat/ tidak berisiko dengan nilai 370 (72,55\%). Kemudian indikator dengan skor tertinggi terdapat pada indikator pada penilaian kinerja diterangkan secara jelas mengenai target apa yang diharapkan dari pegawai dengan skor 407 (79,80\%).

Berdasarkan tanggapan dari responden terhadap kompensasi, dapat diketahui sejauh mana gambaran tanggapan responden terhadap variabel kompensasi. Rata-rata skor dari jawaban responden untuk variabel kompensasi mencapai skor sebesar 367,93 $(72,14 \%)$, yang artinya secara kualitatif tanggapannya masuk ke dalam kategori baik. Selanjutnya diketahui indikatoryang memiliki skor terendah, yaitu sebesar $303(59,41 \%)$ terdapat pada tunjangan hari raya yang diberikan perusahaan cukup memuaskan,

Tabel 3 Hasil Uji Statistik Analisis Jalur Pengaruh Secara Parsial $X_{1}$ terhadap $Y$

\begin{tabular}{lllllll}
\hline $\begin{array}{l}\text { Pengaruh } \mathbf{X}_{1} \\
\text { terhadap } \mathbf{Y}\end{array}$ & Koefisien & $\mathbf{P Y}_{\mathbf{X} 1}$ & $\mathbf{t}_{\text {hitung }}$ & $\mathbf{t}_{\text {tabel }}$ & Keputusan & Signifikansi \\
\hline Langsung & 0,162 & & & & Ho ditolak & Signifikan \\
Melalui $X_{2}$ & 0,107 & 0,403 & 4,038 & 1,984 & & \\
Total Pengaruh $X_{1}$ & 0,270 & & & & \\
\hline
\end{tabular}


Tabel 4 Hasil Uji Statistik Analisis Jalur Pengaruh Secara Parsial $X_{2}$ terhadap Y

\begin{tabular}{llccccc}
\hline $\begin{array}{l}\text { Pengaruh } \mathbf{X}_{1} \\
\text { terhadap Y }\end{array}$ & Koefisien & $\mathbf{P Y}_{\mathbf{X} 1}$ & $\mathbf{t}_{\text {hitung }}$ & $\mathbf{t}_{\text {tabel }}$ & Keputusan & Signifikansi \\
\hline Langsung & 0,139 & & & & & \\
Melalui X & 0,107 & 0,373 & 3,739 & 1,984 & Ho ditolak & Signifikan \\
Total Pengaruh $\mathrm{X}_{1}$ & 0,247 & & & & & \\
\hline
\end{tabular}

sedangkan indikator jumlah kehadiran di tempat kerja memengaruhi kompensasi dan menempati skor tertinggi yaitu 398 (78,04\%).

Pengaruh penilaian prestasi kerja terhadap kinerja dapat dilihat pada Tabel 3. Hipotesis pertama adalah penilaian prestasi kerja memengaruhi kinerja individu dapat diterima. Pengaruh kompensasi terhadap kinerja dapat dilihat pada Tabel 4. Dari hasil perhitungan, diperoleh nilai t hitung sebesar 3,739 (>1,984). Dengan demikian, hipotesis yang menyatakan kompensasi memengaruhi kinerja dapat diterima. Hipotesis ketiga adalah penilaian prestasi kerja memengaruhi kompensasi. Dari hasil perhitungan, diperoleh nilai t hitung sebesar $10,208(>1,984)$. Dengan demikian, hipotesis yang menyatakan penilaian prestasi kerja memengaruhi kompensasi dapat diterima. Pengaruh penilaian prestasi kerja terhadap kompensasi dan implikasinya terhadap kinerja dapat dilihat pada Tabel 5. Berdasarkan Tabel 6 diperoleh nilai $\mathrm{F}$ hitung sebesar 104,203 $>F$ tabel $(F(0,05,2,61)=3,088)$. Terbukti bahwa penilaian kinerja dan kompensasi secara bersama-sama berpengaruh terhadap variabel kinerja. Pengaruh penilaian prestasi kerja dan kompensasi terhadap kinerja mencapai 51,68\%. Oleh karena itu, selain dipengaruhi penilaian kinerja dan kompensasi kinerja juga dipengaruhi oleh variabel lainnya yang tidak diteliti.

\section{Pembahasan}

Gambaran tanggapan responden terhadap kinerja mencapai skor 415,8 atau $81,54 \%$, yang artinya secara kualitatif termasuk dalam kategori sangat baik. Kinerja individu harus selalu dinilai dan dievaluasi karena akan memengaruhi kinerja organisasi. ${ }^{19}$ Tercapai atau tidaknya target kinerja individu akan memengaruhi target kinerja organisasi. Pada penelitian ini juga dapat diketahui indikator yang memiliki skor paling tinggi adalah berusaha untuk jujur dalam menjalankan setiap pekerjaan yang diberikan $(88,04 \%)$. Hal ini sangat penting mengingat instalasi farmasi diberi tanggung jawab untuk mengelola obat-obatan dan alat kesehatan dengan aset yang sangat besar.

Indikator yang paling rendah pada tanggapan responden terhadap kinerja adalah tingkat kehadiran datang ke kantor sesuai dengan waktu yang sudah ditetapkan. Hasil penelitian ini sesuai dengan masalah yang peneliti tulis pada latar belakang, bahwa kedisiplinan kehadiran tepat waktu Tenaga Teknis Kefarmasian instalasi farmasi masih rendah. Rendahnya kedisiplinan/ kehadiran tepat waktu dapat memengaruhi mutu pelayanan instalasi farmasi, sehingga

Tabel 5 Hasil Uji Statistik Analisis Jalur Pengaruh Secara Langsung $X_{1}$ terhadap $X_{2}$

\begin{tabular}{lccccc}
\hline Variabel & $\mathbf{P Y}_{\mathbf{x} \mathbf{1}}$ & $\mathbf{t}_{\text {hitung }}$ & $\mathbf{t}_{\text {tabel }}$ & Keputusan & Signifikansi \\
\hline $\mathrm{X}_{1}$ terhadap $\mathrm{X}_{2}$ & 0,373 & 3,739 & 1,984 & Ho ditolak & Signifikan \\
\hline
\end{tabular}


Tabel 6 Hasil Uji Statistik Analisis Jalur Substruktur 1

\begin{tabular}{|c|c|c|c|}
\hline Parameter & Koefisien & Keterangan & Signifikansi \\
\hline F hitung & 104,203 & Ho ditolak & Signifikan \\
\hline$F_{(005261)}$ & 3,088 & & \\
\hline $\mathrm{R}_{\mathrm{YX} 1 \mathrm{X} 2}^{(0,05,2,61)}$ & 0,517 & $\begin{array}{l}\text { Pengaruh secara simultan X1 dan X2 terhadap Y } \\
\text { sebesar } 51,68 \%\end{array}$ & \\
\hline $\mathrm{R}^{2} \mathrm{Y}_{\mathrm{e} 1}$ & 0,695 & Pengaruh variabel lain terhadap Y sebesar $48,32 \%$ & \\
\hline
\end{tabular}

memengaruhi kinerja unit instalasi farmasi. Remunerasi yang baru diberlakukan di RSUP Dr. Hasan Sadikin merupakan penghargaan terhadap kinerja pegawai yang seharusnya diberikan dengan adil sesuai dengan kinerjanya. Kehadiran merupakan salah satu faktor yang dinilai dan dapat memengaruhi besarnya nilai remunerasi yang diperoleh. Dengan adanya remunerasi, diharapkan menjadi motivasi bagi karyawan untuk dapat hadir tepat waktu. Hal ini sesuai dengan hasil penelitian Jamil, B dan Raja, N.S., bahwa kompensasi secara signifikan dapat meningkatkan kinerja karyawan. ${ }^{19}$

Hasil penelitian ini menunjukkan bahwa penilaian prestasi kerja memengaruhi kinerja pegawai. Hal ini sesuai dengan Denisi dan Pritchaard dalam Selvarajan dan Cloninger mengenai penelitian penilaian kinerja yang menunjukkan bahwa karakteristik penilaian kinerja dapat menimbulkan reaksi positif karyawan untuk penilaian kinerja yang pada gilirannya dapat memotivasi karyawan untuk meningkatkan kinerja mereka. ${ }^{10,20,21}$ Dari jawaban kuesioner diperoleh penilaian kinerja memperoleh skor 389,5 atau 76,37\% yang artinya secara kualitatitif masuk dalam kategori baik tanggapannya. Selanjutnya, diketahui pula indikator yang memiliki skor terendah terdapat pada penilaian kinerja dibebankanberdasarkanrisikokerja(72,55\%).

Risiko kerja pada penilaian prestasi kerja termasuk dalam penilaian kondisi kerja, yang pada sistem penilaiannya antara risiko kerja dan nilainya tidak signifikan sehingga SDM instalasi farmasi yang bekerja di daerah risiko kerja yang tinggi, seperti unit pencampuran obat kemoterapi, mendapat nilai yang tidak jauh dengan SDM yang bekerja di unit lain. Hasil penilaian kinerja memengaruhi remunerasi yang diperoleh, yang artinya remunerasi yang diperoleh SDM unit kerja pencampuran sitotoksik tidak berbeda jauh dengan remunerasi yang diperoleh SDM unit lain. Sistem penilaian kinerja yang diterapkan merupakan aturan yang ditetapkan oleh Kementerian Kesehatan.

Indikator tertinggi pada variabel penilaian kinerja terdapat pada penilaian kinerja diterangkan secara jelas mengenai target apa yang diharapkan pegawai dengan nilai $79,8 \%$. Sistem penilaian prestasi yang sekarang diterapkan memperhatikan hal-hal sebagai berikut, yaitu jelas, dapat diukur, dapat dicapai, dan mempunyai target, sedangkan sistem penilaian yang diterapkan pada penilaian DP3, perhitungan insentif, dan sistem merit lebih berfokus pada penilaian kepribadian, perilaku, dan bukan berdasarkan pada kinerja pegawai. Pada sistem penilaian pegawai yang sekarang diterapkan, pegawai mengetahui secara jelas target yang harus dicapai, dan hasil penilaian dapat diketahui secara transparan karena hasil penilaian harus ditandatangani oleh pegawai yang bersangkutan, sehingga pegawai dapat mengukur hasil yang diperoleh dan dapat meningkatkan target yang belum tercapai pada bulan berikutnya. ${ }^{22}$

Hasil penelitian ini menunjukkan bahwa kompensasi memengaruhi kinerja pegawai. Hal ini sesuai dengan penelitian oleh Umar G., 
bahwa imbalan dalam bentuk apapun memotivasi karyawan untuk bersedia bekerja lebih baik lagi. ${ }^{15}$ Dari jawaban kuesioner yang diperoleh, didapatkan kompensasi mencapai skor sebesar 367,93 (72,14\%), yang artinya secara kualitatif termasuk dalam kategori baik tanggapannya. Indikator yang memiliki skor terendah adalah tunjangan hari raya yang diberikan perusahaan cukup memuaskan. Sebelum diberlakukan sistem remunerasi, Instalasi Farmasi RSUP Dr. Hasan Sadikin mendapatkan jasa pelayanan setiap bulan yang besarnya bergantung pada pendapatan rumah sakit. Jasa pelayanan farmasi yang diberikan sebagian dibagikan dalam bentuk insentif farmasi setiap bulan dan sebagian disimpan untuk pembayaran tunjangan hari raya, liburan SDM (karyawisata karyawan), pengembangan SDM, dan lain-lain. Setelah remunerasi diberlakukan, instalasi farmasi tidak mendapatkan lagi jasa dari pelayanan farmasi. Semuapendapatansudah dimasukkan ke dalam remunerasi yang diberikan kepada individu. Pengambilan kuesioner dilakukan setelah sistem remunerasi diberlakukan, dan SDM tidak akan memperoleh lagi tunjangan hari raya seperti yang selama ini diberikan sehingga indikator pada variabel kompensasi ini memiliki nilai terendah.

Indikator yang tertinggi pada variabel kompensasi adalah jumlah kehadiran di tempat kerja memengaruhi kompensasi (78,04\%). Sebelum remunerasi diberlakukan, instalasi farmasi sudah membuat penilaian kinerja. Penilaian kinerja ini digunakan untuk menentukan besarnya penghasilan tambahan yang diberikan. Penghasilan tambahan yang diberikan sebelum sistem remunerasi merupakan suatu pemberian sistem merit yang diberikan oleh rumah sakit berdasarkan penilaian yang diberikan oleh unit kerja dalam hal ini instalasi farmasi, dan insentif farmasi yang dikeluarkan oleh instalasi farmasi dari jasa pelayanan farmasi yang didapatkan dari rumah sakit. Pada penilaian yang diterapkan, kehadiran merupakan salah satu faktor yang bisa memengaruhi penghasilan tambahan karyawan, baik sistem merit maupun insentif farmasi. Semakin tinggi jumlah kehadiran, semakin tinggi pula penghasilan yang didapatkan. Demikian pula semakin rendah jumlah kehadiran, penghasilan yang didapat pun akan semakin rendah.

Hasil penelitian ini menunjukkan bahwa penilaian prestasi kerja memengaruhi kompensasi. Pengaruh langsung penilaian pada prestasi kerja terhadap kompensasi mempunyai nilai sebesar $51,03 \%$. Hal ini berarti ada faktor lain yang memengaruhi kompensasi di samping penilaian prestasi kerja. Faktor lain yang bisa memengaruhi kompensasi, selain penilaian prestasi kerja pada Rumah Sakit BLU diantaranya, adalah pendapatan atau keuangan rumah sakit, karena remunerasi yang dibagikan berdasarkan pendapatan rumah sakit yang diterima.

Hasil penelitian ini juga menunjukkan bahwa penilaian terhadap prestasi kerja dan kompensasi berpengaruhterhadapkinerja, baik secara sendiri-sendiri maupun secara simultan (bersama). Artinya, apabila variabel-variabel penilaian kinerja dan kompensasi dikelola secara lebih baik, maka akan berdampak pada peningkatan pada kinerja pegawai. ${ }^{20}$

Kontribusi total dari variabel yang diteliti yaitu penilaian kinerja dan kompensasi mencapai skor 51,68\%. Berdasarkan hasil tersebut dapat dilihat bahwa di samping pengaruh penilaian kinerja dan kompensasi, masih ada faktor lain yang ikut berpengaruh terhadap kinerja, yaitu sebesar 48,32. Hal ini sesuai dengan penelitian Muogbo dan Uju (2013) bahwa terdapat beberapa faktor ekstrinsi seperti kondisi kerja, keamanan, promosi kerja, kebijakan organisasi dapat memengaruhi kinerja pegawai. ${ }^{23}$

\section{Simpulan}

Penilaian prestasi kerja memengaruhi kinerja 
individu, baik secara langsung maupun melalui kompensasi. Pengaruh penilaian prestasi kerja terhadap kinerja secara langsung lebih besar dibandingkan dengan pengaruh penilaian prestasi kerja melalui kompensasi. Pengaruh total penilaian prestasi kerja terhadap kinerja sebesar 27,0\%. Kompensasi memengaruhi kinerja individu secara langsung maupun melalui penilaian prestasi kerja dengan pengaruh total sebesar $24,68 \%$. Penilaian prestasi kerja memengaruhi kompensasi dengan nilai 51,03\%. Variabel penilaian prestasi kerja mempunyai pengaruh paling besar terhadap kinerja dibandingkan dengan variabel kompensasi.

\section{Pendanaan}

Penelitian ini tidak didanai oleh sumber hibah manapun.

\section{Konflik Kepentingan}

Tidak terdapat potensi konflik kepentingan dengan penelitian, kepenulisan (authorship), dan atau publikasi artikel ini.

\section{Daftar Pustaka}

1. Keputusan Menteri Keuangan No. 376/ KMK.05/2014 Tentang Remunerasi.

2. Peraturan Pemerintah Nomor 46 Tahun 2011 Tentang Penilaian Prestasi Kerja Pegawai Negeri Sipil.

3. Pribadi JA, Harjanti, D. Pengaruh penilaian prestasi kerja terhadap motivasi kerja karyawan dengan kompensasi sebagai variabel intervening pada PT. Enseval Putera Megatrading Cabang Surabaya 2. Agora. 2014;2(1).

4. Widyatmini, Hakim L. Hubungan kepemimpinan, kompensasi dan kompetensi terhadap kinerja pegawai Dinas Kesehatan Kota Depok. Jurnal Manajemen dan Bisnis. 2008;13(2):163-
70.

5. Ruyatnasih HY, Nelly M, Asep YH. Pengaruh kompensasi terhadap prestasi kerja karyawan pada divisi engineering PT Bridgestone Karawang. Jurnal Manajemen. 2013;10(3):1087-92.

6. Mangkunegara AP. Manajemen sumber daya manusia perusahaan. Bandung: PT Rosdakarya; 2012.

7. Katerina V, Andrea S, Gabriela K. Identification of employee performance appraisal methods in agricultural organizations. J Competitiveness. 2013; 5(2):20-36. doi: 10.7441/joc.2013.02.02

8. Subhangi S, Shalini S, Priyanka S, Pratibha S. Performance appraisal and career development. VSRD Int J Business Man Res. 2012;2(1):8-16.

9. Daoanis LE. Performance appraisal system: it's implication to employee performance. Int J Econ Man Sci. 2012; 2(3):55-62.

10. Selvarajan TT, Cloninger PA. Can performance appraisals motivate employees to improve performance? a Mexican study. Int J Hum Resour Man. 2011;23(5):1-22. doi:10.1080/09585192. 2011.637069

11. Patnaik BCM, Padhi PC. Compensation management: a theoretical preview. Trans AsianJMarketManRes. 2012;1(1):39-44.

12. Khan W, Mufti EO. Effect of compensation on motivating employees in public and private banks of Peshawar (BOK and UBL). J Basic Appl Sci Res. 2012; 2(5):4616-23.

13. Astuti DALW. Penciptaan sistem penilaian kinerja yang efektif dengan assessment center. Jurnal Manajemen. 2006;6(1):23-33.

14. Umar G. The influence of compensation on performance of sales representatives of pharmacetical companies based in Ilorin-Nigeria. Int Multi-Disciplinary J. 2010;4(3b):223-39. doi: 10.4314/afrrev. 
v4i3.60258

15. Katua, Ngui T, Mukulu E, Gachunga HG. Effect of reward and compensation strategies on the performance of commercial banks in Kenya. Int $\mathrm{J}$ Edu Res. 2014; 2(1):1-16.

16. Notoatmodjo S. Metodologi penelitian kesehatan. Jakarta: Rineka Cipta; 2010.

17. Sarwono J. Analisis jalur untuk riset bisnis dengan SPSS. Yogyakarta: Andi offset; 2007.

18. Riduan. Skala pengukuran variabelvariabel penelitian. Bandung: Alfabeta; 2012

19. Obisi C. Employee performance appraisal implications for individual and organitational growth. Aust J Bus Man Res. 2011;1(9):92-7.

20. Purwaningrum EL, Musadieq MA,
Ruhana I. Pengaruh penilaian kinerja terhadap semangat kerja (studi pada karyawan tetap PT. Aggiomultimex). Jurnal Administrasi Bisnis. 2014;8(2): $1-10$.

21. Jamil B, Raja NS. Impact of compensation performance evaluation and promotion practices on government employees performance vs private employees performance. Interdiscipl J Contemp Res Bus. 2011;3(8):907-12.

22. Singh R, Mohanty M. Performance appraisal practices in indian service and manufacturing sector organizations. Asian J Man Res. 2013;4(2): 256-65.

23. Muogbo US. The influence of motivation on employees' performance: a study of some selected firms in Anambra State. Intl J ArtsHumanities. 2013;2(3):134-51. 